\title{
A mikro-RNS-ek patogenetikai és diagnosztikai szerepe mellékvesekéreg-carcinomában
}

\author{
Nagy Zoltán dr. - Decmann Ábel dr. - Perge Pál dr. - Igaz Péter dr.
}

Semmelweis Egyetem, Általános Orvostudományi Kar, II. Belgyógyászati Klinika, Budapest

\begin{abstract}
A mellékvesekéreg daganatos elváltozásai a népesség jelentős részét érintik. E daganatok többsége jóindulatú, hormonálisan inaktív mellékvesekéreg-adenoma. A ritka hormontermelő mellékvesekéreg-adenomák súlyos klinikai következményekkel járó betegségeket okoznak, a kifejezetten ritka mellékvesekéreg-carcinoma prognózisa ugyanakkor előrehaladott stádiumaiban nagyon rossz. E daganatok patogenezise a mai napig nem teljesen tisztázott. A mikroRNS-ek kisméretű nem kódoló RNS-molekulák, amelyek a génexpresszió poszttranszkripciós szabályozása révén jelentős szerepet töltenek be számos alapvető sejtbiológiai folyamatban. Megváltozott kifejeződésüket számos daganatban leírták. Több szöveti mikro-RNS, így a $m i R-483-5 p$, a $m i R-503$, a $m i R-210$, a $m i R-335$ és a $m i R-195$ megváltozott kifejeződését találták jó- és rosszindulatú mellékvese-daganatok között, és ezeknek patogenetikai jelentőségük is lehet. A mikro-RNS-ek szövetspecifikus és stabil kifejeződésüknek köszönhetően a diagnosztikában is felhasználhatók lehetnek. Tekintettel arra, hogy a mellékvesekéreg-daganatok szövettani diagnózisa nehéz, a szöveti mikro-RNS-ek segíthetnek a malignitás megállapításában is. Új eredmények igazolták, hogy a mikro-RNS-ek különböző testnedvekbe is kiválasztódnak, ami a folyadékbiopszia módszere révén biomarkerként történő felhasználhatóságukat vetíti előre. Összefoglaló cikkünkben a mikro-RNS-ek mellékvesekéreg-daganatokban betöltött patogenetikai szerepét és diagnosztikai alkalmazási lehetőségeit tekintjük át.
\end{abstract}

Orv Hetil. 2018; 159(7): 245-251.

Kulcsszavak: mellékvesekéreg-rák, mikro-RNS, szöveti, keringő, extracellularis vesicula

\section{Pathogenic and diagnostic roles of microRNAs in adrenocortical tumours}

Adrenocortical tumours are quite prevalent. Most of these tumours are benign, hormonally inactive adrenocortical adenomas. Rare hormone-secreting adrenocortical adenomas are associated with severe clinical consequences, whereas the prognosis of the rare adrenocortical cancer is rather poor in its advanced stages. The pathogenesis of these tumours is only partly elucidated. MicroRNAs are small, non-coding RNA molecules that are pivotal in the regulation of several basic cell biological processes via the posttranscriptional regulation of gene expression. Their altered expression has been described in many tumours. Several tissue microRNAs, such as $m i R-483-5 p, m i R-503$, $m i R-210, m i R-335$ and $m i R-195$ were found to be differentially expressed among benign and malignant adrenocortical tumours, and these could also have pathogenic relevance. Due to their tissue specific and stable expression, microRNAs can be exploited in diagnostics as well. As the histological diagnosis of adrenocortical malignancy is difficult, microRNAs might be of help in the establishment of malignancy. Novel data show that microRNAs are secreted in various body fluids, projecting their applicability as biomarkers as part of liquid biopsy. In this review, we attempt to present a synopsis on the pathogenic relevance of microRNAs in adrenocortical tumours and their potential diagnostic applicability.

Keywords: adrenocortical cancer, microRNA, tissue, circulating, extracellular vesicle

Nagy Z, Decmann Á, Perge P, Igaz P. [Pathogenic and diagnostic roles of microRNAs in adrenocortical tumours]. Orv Hetil. 2018; 159(7): 245-251.

(Beérkezett: 2017. augusztus 28.; elfogadva: 2017. szeptember 21.) 


\section{Rövidítések}

$\mathrm{ACA}=$ mellékvesekéreg-adenoma; $\mathrm{ACC}=$ mellékvesekéregrák; $\mathrm{NA}=$ normál mellékvesekéreg-szövet; NGS = next generation sequencing; TLDA = TaqMan low-density array; qRT-PCR = valós idejű kvantitatív reverz transzkripciós polimeráz-láncreakció

A mellékvesekéreg daganatos elváltozásai gyakoriak, boncolási adatok alapján a népesség 1,4-6\%-át érintik [1, 2]. Bár ezek nagy része hormonálisan inaktív jóindulatú daganatként nem okoz tünetet, s csupán véletlenszerủen, más betegség kapcsán végzett képalkotó vizsgálat során fedezik fel (incidentaloma) [3], a ritka hormonszekretáló adenomák súlyosan ronthatják a betegek életminőségét. A mellékvesekéreg-rák ugyanakkor egy igen ritkán előforduló (incidencia: 0,5-2/millió/év), rossz prognózisú, agresszív daganat, mely a mai napig kihívást jelent mind diagnosztikai, mind kezelési szempontból. Ebben a daganattípusban nem áll rendelkezésünkre megbízható, malignitást jelző preoperatív marker, a szövettani diagnózis nehézkes, valamint kezelésében is korlátozottak a lehetôségeink [4].

A mellékvesekéreg-rák patogenezisét az utóbbi évek kutatásainak köszönhetően egyre jobban ismerjük, de még messze állunk attól, hogy átfogó képünk lenne a tumor kialakulásának mechanizmusáról. A korábbi, örökletes mellékvesekéreg-rákokat vizsgáló tanulmányokban meghatározott inzulinszerú növekedési faktor-2- (IGF-2), TP53- és Wnt/B-katenin jelátviteli útvonalak szerepét a modern nagy áteresztőképességú módszerek megerősítették, valamint eredményeik alapján a daganatokat jó- és rosszindulatúság, prognózis alapján csoportokra tudták osztani [5].

A mellékvesekéreg-daganatok esetében számos diagnosztikai probléma is felmerül. Preoperatívan a képalkotó diagnosztika sokszor nehéz, nem rendelkezünk egy megbízható, rosszindulatúságot egyértelmúen jelző laboratóriumi markerrel, posztoperatívan pedig a szövettani diagnózis még gyakorlott patológus számára is nagy kihívást jelent [4].

A mikro-RNS-ek (miRNS) kis, nem kódoló, egyszálú RNS-molekulák, melyek a hírvivő (messenger) RNS (mRNS) 3'-UTR- (nem transzlálódó) régiójához specifikusan kötődve képesek gátolni annak transzlációját, így a génexpresszió poszttranszkripciós szabályozása révén az epigenetikai folyamatok egyik kulcsszereplői. Újabb adatok szerint a sejtmagban is fontos szerepük van a génátíródás szabályozásában [6]. Számos élettani folyamat irányításában játszanak szerepet, s központi feladatot töltenek be alapvető sejtbiológiai folyamatokban, mint például a sejtszaporodás, a sejtdifferenciáció és az apoptózis. Megváltozott kifejeződésüket számos daganatban leírták [7].

Azon miRNS-eket, melyek a sejtproliferációt, a sejtmigrációt és az angiogenezist serkentik, illetve csökkentik a tumorszuppresszor mRNS-ek szintjét, elősegítve ezáltal a daganatok növekedését, onkogén miRNS-eknek (oncomiR), míg azokat, melyek a daganatok növekedését gátolják, tumorszuppresszor miRNS-eknek nevezzük [8].

A mikro-RNS-ek fontos jellemzője, hogy kifejeződésük szövet- és tumorspecifikus, így mintázatukat meghatározva felhasználhatók lehetnek különböző tumorok diagnosztizálására, azok prognózisának megállapítására, $\mathrm{s}$ akár a tumorellenes kezelés hatásosságának monitorozására [9]. Ez a lehetőség elsősorban azokban a daganatokban jelentős, melyek pre- és posztoperatív diagnosztikája nehézkes, így például a mellékvesekéreg-rák esetében is. Az utóbbi években derült fény arra, hogy jelen vannak különböző testfolyadékokban is, mint például vér, vizelet, széklet, nyál, anyatej stb. Ezek a miRNS-ek a keringő miRNS-ek, melyek a viszonylag egyszerú mintavételnek köszönhetően a jövő́ben különböző betegségek, tumorok potenciális biomarkereivé válhatnak [10] a folyadékbiopszia részeként.

A mellékvesekéreg-rák és a miRNS-ek kapcsolatát több munkacsoport, így a miénk is vizsgálta. A következőkben a mellékvesekéreg-daganatok patogenezisében és kórisméjében fontos mikro-RNS-eket mutatjuk be.

\section{Szöveti miRNS-ek és a mellékvesekéreg-rák}

A mai napig összesen 11 tanulmány vizsgálta a szöveti miRNS-ek kifejeződését mellékvesekéreg-daganatokban $[5,9,11-19]$. E vizsgálatokban a mellékvesekéreg-daganatszövetekból izolálnak RNS-t, majd ezekben a mintákban vizsgálják a miRNS-ek kifejeződését különböző módszerekkel (pl. polimeráz-láncreakción, újgenerációs szekvenáláson, microarray-en alapuló módszerek). Eredményeik közül a tanulmányok legalább felében validált miRNS-ek patogenetikai szerepét részletezzük (1. táblázat).

\section{A miR-483-5p és a miR-483-3p}

A $m i R-483-5 p$ és a $m i R-483-3 p$ mint a $m i R-483$-ról átíródó két miRNS fokozott kifejeződését szinte az összes vizsgálat igazolta. A miR-483 génje a mellékvesekéregrákban szintén fokozottan kifejeződő és fontos patogenetikai szereplőként leírt IGF2-gén második intronjában található. A miR-483-5p pontos funkcióját nem ismerjük, de fontos megfigyelés, hogy egy pozitív visszacsatolási hurkon keresztül fokozni képes az IGF2 expresszióját [20], sőt HeLa-sejteken a saját kifejeződését is fokozta [21]. Prostatarákban leírták proliferációt fokozó hatását, melyet a Wnt/ß-katenin jelátvitelt gátló RBM5 kifejeződésének gátlásával fejtett ki [22]. Ezenfelül tüdőadenocarcinoma-sejtvonalon a Wnt/B-katenin jelátvitel aktiválta fokozott átíródását, és a sejtek migrációjára gyakorolt pozitív hatását azonosították [23]. A miR-483-3p egyik célpontját ugyanakkor validálták, amely a p53-as fehérjével kapcsolatban álló PUMA tumorszuppresszor, s ennek gátlásával fejti ki onkogén ha- 
1. táblázat | Szignifikánsan megváltozott szöveti mikro-RNS-ek a mellékvesekéreg-rákot vizsgáló tanulmányokban

\begin{tabular}{|c|c|c|c|c|}
\hline $\begin{array}{l}\text { Szerző, évszám } \\
\text { [hivatkozási szám] }\end{array}$ & $\begin{array}{l}\text { Az elemzés } \\
\text { módszere }\end{array}$ & $\begin{array}{l}\text { A vizsgált daganatminták } \\
\text { megoszlása }\end{array}$ & $\begin{array}{l}\text { Fokozott kifejeződés ACC-ben } \\
\text { ACA-hoz és NA-hoz képest }\end{array}$ & $\begin{array}{l}\text { Csökkent kifejeződés ACC-ben } \\
\text { ACA-hoz és NA-hoz képest }\end{array}$ \\
\hline $\begin{array}{l}\text { Tömböl és mtsai, } \\
2009 \text { [9] }\end{array}$ & TLDA & $\begin{array}{l}7 \text { ACC, } 19 \text { ACA, } \\
10 \mathrm{NA}\end{array}$ & miR-503, miR-184, miR-210 & miR-214, miR-511, miR-375 \\
\hline $\begin{array}{l}\text { Soon és mtsai, } \\
2009 \text { [15] }\end{array}$ & microarray & $\begin{array}{l}22 \text { ACC, } 27 \text { ACA, } \\
4 \text { NA }\end{array}$ & $\operatorname{miR}-483-5 p$ & miR-195, miR-335 \\
\hline $\begin{array}{l}\text { Patterson és mtsai, } \\
2011[16]\end{array}$ & microarray & $\begin{array}{l}10 \mathrm{ACC}, 26 \mathrm{ACA} \text {, } \\
21 \mathrm{NA}\end{array}$ & $\operatorname{miR}-483-3 p, m i R-483-5 p$ & miR-100, miR-125-b, miR-195 \\
\hline $\begin{array}{l}\text { Özata és mtsai, } \\
2011[14]\end{array}$ & microarray & $\begin{array}{l}25 \text { ACC } 43 \text { ACA, } \\
10 \text { NA }\end{array}$ & $\begin{array}{l}\text { miR-483-5p, miR-483-3p, } \\
\text { miR-210, miR-21, } \\
\text { miR-503, miR-1202, miR-1275 }\end{array}$ & miR-1974, miR-195, miR-497 \\
\hline $\begin{array}{l}\text { Schmitz és mtsai, } \\
2011[12]\end{array}$ & TLDA & $4 \mathrm{ACC}, 9 \mathrm{ACA}, 4 \mathrm{NA}$ & miR-139-5p, miR-675 & miR-335 \\
\hline $\begin{array}{l}\text { Chabre és mtsai, } \\
2013[11]\end{array}$ & microarray & $12 \mathrm{ACC}, 6 \mathrm{ACA}$ & miR-483-5p, miR-139-5p, miR-376a & miR-195, miR-335 \\
\hline $\begin{array}{l}\text { Duregon és mtsai, } \\
2014[18]\end{array}$ & qRT-PCR & $51 \mathrm{ACC}$ & $\begin{array}{l}\text { miR-483-3p, miR-483-5p, } \\
\text { miR-210, miR-195, miR-1974 }\end{array}$ & \\
\hline $\begin{array}{l}\text { Assié és mtsai, } \\
2014 \text { [5] }\end{array}$ & NGS & 45 ACC, 3 NA & $\begin{array}{l}\operatorname{miR}-483-3 p, \operatorname{miR}-483-5 p, \\
\text { miR-210, miR-503, miR-184, } \\
\text { miR-139-5p, miR-376a }\end{array}$ & $\begin{array}{l}\operatorname{miR}-195, \text { miR-335, } \operatorname{miR}-214 \\
\text { miR-497 }\end{array}$ \\
\hline $\begin{array}{l}\text { Feinmesser és mtsai, } \\
2015 \text { [13] }\end{array}$ & microarray & 17 ACC, 29 ACA & $\begin{array}{l}\operatorname{miR}-483-5 p, \operatorname{miR}-483-3 p \\
\text { miR-503, miR-210 }\end{array}$ & $\begin{array}{l}\text { miR-195, miR-335, miR-214, } \\
\text { miR-125b, miR-497 }\end{array}$ \\
\hline $\begin{array}{l}\text { Gara és mtsai, } \\
2015 \text { [19] }\end{array}$ & microarray & $\begin{array}{l}10 \mathrm{ACC}, 26 \mathrm{ACA}, \\
21 \mathrm{NA}\end{array}$ & $\begin{array}{l}\text { miR-9, miR-25, miR-124, miR-183, } \\
\text { miR-185, miR-206 }\end{array}$ & \\
\hline $\begin{array}{l}\text { Kopersky és mtsai, } \\
2017 \text { [17] }\end{array}$ & NGS & $\begin{array}{l}15 \mathrm{ACC}, 18 \mathrm{ACA} \text {, } \\
18 \mathrm{NA}\end{array}$ & $\begin{array}{l}\text { miR-509-5p, miR-184, miR-503-5p, } \\
\text { miR-483-3p, miR-483-5p, } \\
\text { miR-210, miR-542-3p, miR-450b-5p }\end{array}$ & \\
\hline
\end{tabular}

A vastagon szedett mikro-RNS-eket validálták legalább 4 tanulmányban.

ACA = mellékvesekéreg-adenoma; ACC = mellékvesekéreg-rák; NA = normál mellékvesekéreg-szövet; NGS = next generation sequencing; TLDA = TaqMan low-density array; qRT-PCR = valós idejű kvantitatív reverz transzkripciós polimeráz-láncreakció

tásait [24]. A miR-483-5p fokozott kifejeződését a mellékvesekéreg-carcinoma prognózisával is kapcsolatba hozták.

\section{A miR -503}

Mellékvesekéreg-rákban a miR-503 kifejeződését szignifikánsan magasabbnak találta több munkacsoport, így a miénk is, sőt prognosztikai jelentőségét is felvetették [9, 14]. Jelenleg a $m i R-503$-nak a mellékvesekéreg-rák patogenezisében betöltött szerepe tisztázatlan. Több daganatban tumorszuppresszori szerepét feltételezik, pl. hepatocellularis és emlőrák, glioblastoma multiforme esetén az IGFl receptorának, valamint a ciklin-Dl- és -D3-nak a gátlása révén csökkentette a sejtek proliferációját, migrációját és az angiogenezist [25-27].

\section{A $\operatorname{miR}-210$}

A $m i R-210$ fokozott kifejeződése - a $m i R-483-5 p$-hez hasonlóan - szintén a mellékvesekéreg-rák agresszívebb viselkedésével és rosszabb prognózisával társul [18]. Kifejeződése nagyban függ a szövet oxigénellátottságától, míg normoxiás állapotokban a szintje minimális, addig hypoxiás körülmények között kifejeződése a HIF-l $\alpha$ transzkripciós faktor hatására nagyban emelkedik. A $m i R-210$-et tekintik a fó hypoxia indukálta miRNS-nek (hypoxamiR). Elősegíti a tumoros folyamatok progreszszióját, befolyásolja a sejtciklus szabályozását, az apoptózist, a mitokondrium funkcióját, az angiogenezist és a sejtek metasztázisképző hajlamát is $[28,29]$. Célpontjai között például a sejtciklus szabályozásáért felelős E2F3 transzkripciós faktor, valamint az $\mathrm{NF}_{k} \mathrm{~B}$ jelátvitel is szerepel. Emelkedett szintjét számos daganatban, például gliomában, malignus melanomában, hasnyálmirigyrákban is leírták [24, 28].

\section{A miR-195}

A mellékvesekéreg-carcinomában csökkent kifejeződésú miRNS-ek közül a miR-195 a legfontosabb [30]. Soon és $m t s a i$ az alacsonyabb kifejeződését rosszabb átlagos túléléssel is összefüggésbe hozták [15], valamint egy in vitro kísérlet során kifejeződésének a fokozása szignifikánsan gátolta a mellékvesekéreg-ráksejtek proliferációját [14]. Számos jelátviteli útvonalat befolyásol, így szabá- 
lyozva a sejtszaporodást, -migrációt, -inváziót stb. Vesesejtes rákban a VEGFR2 [31], vastagbélrákban a CDK8 [32] gátlásával csökkentette a tumorok növekedését, invázióját, valamint indukálta a sejtek apoptózisát. Szintén vesesejtes rákban leírták, hogy befolyásolja a mellékvesekéreg-rák patogenezisében is jelentős szerepet játszó Wnt/ß-katenin útvonalat is [33], valamint intestinalis sejteken az IGF2R transzlációjának miR-195 által kiváltott gátlását validálták [34].

\section{A miR-335}

A miR-335 szignifikánsan csökkent kifejeződését több vizsgálat is validálta. Pontos célpontjait és hatásmechanizmusát mellékvesekéreg-rákban szintén nem ismerjük, a tumor típusától függően tumorszuppresszor és onkogén hatását is igazolták az irodalomban. Míg meningeomákban [35] és colorectalis rákban fokozott kifejeződését igazolták [36], addig hasnyálmirigyrákban [37], osteosarcomában [38], világossejtes veserákban [39] tumorszuppresszorként azonosították, gátolva számos sejtciklusban, sejtmigrációban és apoptózisban fontos szerepet betöltő molekulát. Ezen vizsgálatok közül kiemelendő Dong és mtsai közleménye, melyben leírták, hogy a Wnt/ß-katenin jelátvitel potencírozása csökkentette a $m i R-335$ szintjét [40].

E miRNS-ek lehetséges patogenetikai szerepét az 1 . ábra mutatja be.

\section{Szöveti miRNS-ek a diagnosztikában}

A mellékvesekéreg-daganatok dignitásának megállapítása a mai napig a nagy gyakorlatot igénylö Weiss-score alapján történik [41]. A Weiss-score 9 szövettani paramétert vesz figyelembe (magas mitotikus aktivitás, atípu-

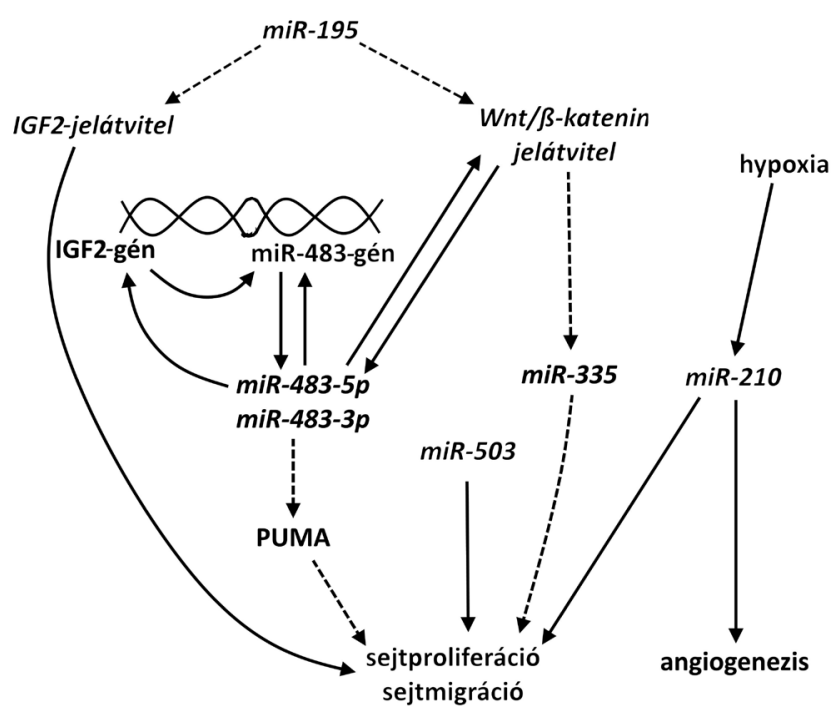

1. ábra

A mellékvesekéreg-rák patogenezisében fontosnak tűnő mikroRNS-ek lehetséges hatásainak sematikus ábrázolása. A folyamatos vonalak serkentést, a szaggatott vonalak gátlást mutatnak sos mitózis, magas nukleáris „grade”, világos citoplazmájú sejtek alacsony aránya, nekrózis, diffúz tumorszerkezet, a tok áttörése, sinusoidalis és vénás invázió), ami alapján a daganat 0 -tól 9 pontig terjedő értéket kaphat. Egyértelműen adenomát a 2 alatti érték, carcinomát pedig a 4 feletti érték jelez. Több vizsgálatban azonosítottak olyan mellékvesekéreg-rákkal kapcsolatos miRNSeket, melyek a jövőben a malignitás és a prognózis megállapítására is felhasználhatók lehetnek.

Saját munkacsoportunk a $m i R-184$ és a $m i R-503$ szignifikánsan fokozott, míg a $m i R-511$ és a $m i R-214$ szignifikánsan csökkent szintjét azonosította mellékvesekéregrákban a mellékvesekéreg-adenomához képest. Ezek között a szöveti $m i R-511$ és $m i R-503$ kifejeződésének különbségét mint lehetséges diagnosztikus markert írtuk le. Ez a marker 100\%-os szenzitivitással és 97\%-os specificitással volt alkalmas a mellékvesekéreg-rák és az adenoma elkülönítésére egy kis elemszámú, 7 mellékvesekéreg-carcinomát magában foglaló vizsgálati rendszerben [9]. Soon és mtsai a miR-335 és a miR-195 csökkent szintjét azonosították mellékvesekéreg-rákban, valamint megállapították, hogy a $m i R-483-5 p$ fokozott kifejeződése, valamint a miR-195 alacsony kifejeződése rosszabb prognózist jelent [15]. Patterson és mtsai az elóbb említett két miRNS-en kívül a miR-100 és a miR-125b csökkent kifejeződését közölték, valamint leírták, hogy a miR-483-5p fokozott kifejeződése elégséges lehet a rosszindulatúság eldöntésére [16]. Feinmesser és mtsai a miR-503 fokozott [13], míg Schmitz munkacsoportja a miR-335 és a miR-675 csökkent kifejeződését azonosították [12] mint a rosszindulatúság legérzékenyebb markereit. Annak ellenére, hogy e vizsgálatok eredményei szerint ezen miRNS-ek segítségével magas specificitással és szenzitivitással lehetett elkülöníteni a jó- és rosszindulatú mellékvesekéreg-daganatokat, a vizsgálatok többségében a kis elemszámok miatt ezek az eredmények nehezen általánosíthatók, így további nagy elemszámú vizsgálatokra lenne szükség. A legkonzekvensebben változó mikro-RNS-ek a magas szöveti $m i R-483-5 p$ és az alacsony miR-195, amelyek elsősorban a rosszabb prognózisú, hamar kiújuló mellékvesekéregrákos esetekre jellemzőek. Több vizsgálat utal arra, hogy a felülexpresszált $m i R-483-5 p$ önmagában is elégséges lehet a jó- és a rosszindulatú mellékvesekéreg-tumorok elkülönítéséhez [14-16].

\section{A keringő miRNS-ek szerepe mellékvesekéreg-rákban}

A szöveteken kívül a miRNS-ek megtalálhatók különböző testfolyadékokban is, ezeket keringő miRNS-eknek nevezzük. A sejtekből három úton juthatnak ki: 1) gyulladás vagy sejthalál következtében passzív kiáramlással; 2 ) extracellularis vesiculumok aktív szekréciójával (ilyenek például: microvesiculum, apoptotikus test, exoszóma); 3 ) illetve makromolekuláris komplexek vagy lipoproteinek segítségével. Így jelen vannak a vérben, az 
anyatejben, a vizeletben, a könnyben, az ondóban, a nyálban, a légúti váladékban és a hasüregi nedvben is. A legnagyobb koncentrációban az anyatej tartalmaz miRNS-eket, míg a legkevesebb miRNS a vizeletben található. Az anyatejre átlagosan $10^{5} \mu \mathrm{g} / \mathrm{L}$, míg a vizeletre $10^{2} \mu \mathrm{g} / \mathrm{L}$ nagyságrend jellemző [10]. A testfolyadékokba kijutott miRNS-ek a magas és alacsony kémhatással, a forralással és a hosszú tárolással szemben is ellenálló, rendkívül stabil molekulák [42]. Az extracellularis miRNS-ek élettani folyamatoknak is közremúködői lehetnek. Az aktív szekrécióval testnedvekbe juttatott, miRNS-t tartalmazó micro- vagy nanovesiculumok más sejteket vehetnek célba. A távoli sejten hatást kiváltva, hormonszerü viselkedésük is feltételezhető. Elméletileg e keringő mikro-RNS-ek nemcsak a szervezeten belül teremthetnek kapcsolatot, hanem egyének, illetve fajok közötti kommunikáció is megvalósulhat segítségükkel. $\mathrm{Az}$ előbbire példaként az anyatejjel átjuttatott, míg az utóbbira a táplálkozás során elfogyasztott növényi és állati miRNS-ek szolgálnak [43], bár e téren számos a bizonytalanság, és jelenleg inkább hipotetikus kapcsolatokról beszélhetünk.

A keringő mikro-RNS-ek minimálisan invazív biomarkerként hatalmas segítséget nyújthatnak pl. egyes daganatok diagnosztikájában is.

Endokrin daganatokra, kórképekre jellemző keringó miRNS-eket eddig viszonylag kis számban fedeztek fel. Mellékvesekéreg-rákos betegek vérében előfordulókat még csak négy tanulmányban vizsgáltak, amelyek közül kettőt munkacsoportunk közölt (2. táblázat).

Chabre és mtsai a mellékvesekéreg daganataira jellemző keringő-miRNS-mintázat kutatásakor azt találták, hogy a miR-195 és a miR-335 kifejeződése szignifikánsan alulmaradt a mellékvesekéreg-adenomához képest. A $m i R-483-5 p$ szérumkoncentrációja az agresszív, gyorsan progrediáló mellékvesekéreg-rákos esetekben magasabb volt a nem agresszív mellékvesekéreg-rákos esetekhez képest [11]. Patel és mtsai a miR-34a szignifikánsabban magasabb szintjét találták mellékvesekéreg- rákosok szérumában, mint adenomásokéban. Ez a szöveti kifejeződéssel éppen ellenkező megfigyelés, ott ugyanis ennek alulreprezentálódását találták, ugyanakkor a szöveti és a keringő miRNS-ek szabályozása nem feltétlenül párhuzamos, illetve a miRNS-ek szekréciójának szabályozási mechanizmusai lényegében ismeretlenek [16]. Ebben a vizsgálatban is leírták a $m i R-483-5 p$ magasabb szintjét az adenomához viszonyítva [44]. Salvianti a $m i R-483-5 p$ abszolút mennyiségi meghatározására tett kísérletet, és talált szignifikánsan magasabb kifejeződést 3-4. stádiumú tumorok esetében 1-2. stádiumú mellékvesekéreg-rákokhoz, adenomákhoz és egészséges mellékvesekéreggel rendelkezőkhöz képest [45].

Szabó és munkacsoportja mind teljes plazmából, mind a plazma extracellularis vesiculumaiból izolált mikroRNS-ekből vizsgálta a keringő mikro-RNS-ek expresszióját. A teljes plazmában a $m i R-100$, a $m i R-181 b$, a $m i R$ 184, a $m i R-210$ és a $m i R-483-5 p$ szignifikánsan magasabb koncentrációját írtuk le adenomákhoz képest. Diagnosztikai felhasználhatóságukat vizsgálva, ROC-analízissel meghatározva, a $m i R-100$ és a $m i R-181 b$ együttes jelenlétekor 77,8\%-os szenzitivitással és 100\%-os specificitással különíthető el az adenoma a mellékvesekéreg-ráktól. Ugyanakkor a $m i R-210$ és a $m i R-181 b$ esetén a szenzitivitás $88,9 \%$-os, míg a specificitás $75 \%$-os volt [46].

A teljes plazmából izolált mikro-RNS-ek mellett tudomásunk szerint munkacsoportunk vizsgálta elsóként az extracellularis vesiculum eredetü (EV) mikro-RNS-ek kifejeződését mellékvesekéreg-daganatos betegekben [47]. Egyes vizsgálati eredmények szerint az EV-eredetű mikro-RNS-ek specifikusabb markerek lehetnek, mint a teljesplazma-eredetűek, mivel az EV-ben lévő mikroRNS-ek aktív szekréció nyomán kerülnek a keringésbe, szemben a teljes plazma mikro-RNS-tartalmával, ami a passzív úton kiszabaduló mikro-RNS-eket (pl. nekrózis, gyulladás) is tartalmazza. Az extracellularis vesiculumok közül biológiai jelentőségüket tekintve a legfontosabbak az exoszómák, amelyek 40-100 nanométer nagyságúak. Az exoszómák az endolizoszomális útvonalon alakulnak

2. táblázat | Szignifikánsan megváltozott keringő mikro-RNS-ek a mellékvesekéreg-rákot vizsgáló tanulmányokban

\begin{tabular}{|c|c|c|c|c|}
\hline $\begin{array}{l}\text { Szerző, } \\
\text { évszám } \\
\text { [hivatkozási szám] }\end{array}$ & $\begin{array}{l}\text { A minta eredete - az elemzés } \\
\text { módszere }\end{array}$ & A minták eloszlása & $\begin{array}{l}\text { Fokozott kifejeződés ACC-ben } \\
\text { ACA-hoz és NA-hoz képest }\end{array}$ & $\begin{array}{l}\text { Csökkent kifejeződés } \\
\text { ACC-ben ACA-hoz és } \\
\text { NA-hoz képest }\end{array}$ \\
\hline Chabre és mtsai, 2013 [11] & Szérum - qRT-PCR & $\begin{array}{l}23 \mathrm{ACC}, \\
4 \text { ACA, } 19 \mathrm{NA}\end{array}$ & miR-483-5p & miR-195, miR-335 \\
\hline Szabó és mtsai, 2013 [46] & Plazma - microarray & $13 \mathrm{ACC}, 12 \mathrm{ACA}$ & $\begin{array}{l}\text { miR-100, miR-181b, miR-184, } \\
\text { miR-210, miR-483-5p }\end{array}$ & miR-195 \\
\hline Patel és mtsai, 2013 [44] & Szérum - qRT-PCR & 17 ACC, 22 ACA & miR-34a, miR-483-5p & \\
\hline Perge és mtsai, 2017 [47] & $\begin{array}{l}\text { Plazma extracellularis } \\
\text { vesiculum - qRT-PCR }\end{array}$ & 22 ACC, 24 ACA & miR-101, miR-483-5p & \\
\hline
\end{tabular}

A vastagon szedett mikro-RNS-eket validálták egynél több tanulmányban.

ACA = mellékvesekéreg-adenoma; ACC = mellékvesekéreg-rák; NA = normál mellékvesekéreg-szövet; qRT-PCR = valós idejű kvantitatív reverz transzkripciós polimeráz-láncreakció 
ki azáltal, hogy a multivesicularis test és a plazmamembrán fuzionál egymással [48]. Perge és mtsai nagy áteresztőképességű és célzott qRT-PCR-rel vizsgálták ezen EV-eredetű mikro-RNS-ek expresszióját mellékvesekéreg-daganatokban. A már több vizsgálatban is mellékvesekéregcarcinoma-specifikusnak leírt $m i R-483-5 p$, illetve az eddig még mellékvesekéreg-daganatokban ismeretlen jelentőségû miR-101 szignifikáns mértékü felülexpreszszálódását mutattuk ki mellékvesekéreg-carcinomában a mellékvesekéreg-adenomákhoz viszonyítva (22 adenoma vs. 24 carcinoma) [47]. Hatásfokmérő karakterisztikával (ROC-analízis) a $m i R-483-5 p$ esetében a diagnosztikában elfogadhatóan magas $87,5 \%$ specificitást és 94,44\% szenzitivitást találtunk. Következtetésként levonható, hogy az EV-eredetü miR-483-5p reményteli minimálisan invazív biomarker lehet a mellékvesekéregrák preoperatív diagnózisában.

Bár humán adatok még nincsenek, a keringő mikroRNS-ek a mellékvesekéreg-carcinoma kezelési hatékonyságának monitorizálására is alkalmasak lehetnek. Munkacsoportunk két egér-xenograftmodellben vizsgálta a keringó mikro-RNS-ek és a daganatok kezelésének kapcsolatát. A már sokszor említett keringő miR-483-5p csökkenését észleltük 9-cisz-retinsav-kezelésre egy NCIH295R mellékvesekéregcarcinoma-sejtvonalból előállított xenograftmodellen [49], míg egy SW-13-as mellékvesekéregcarcinoma-sejtvonalon alapuló modellben a szöveti hypoxiát jelző $m i R-210$ növekedését észleltük liposzomális etopozid-ciszplatin-doxorubicin-mitotán kezelés hatására [50].

\section{Következtetés}

Az utóbbi évek kutatásaiban több adat látott napvilágot, ami a mikro-RNS-ek fontosságát jelzi a mellékvesekéregdaganatok patogenezisében. Feltételezhető patogenetikai szerepük mellett, mind a szöveti, mind a keringő mikro-RNS-ek hasznos elemei lehetnek a mellékvesekéreg-rák diagnosztikájának, és különösen nagy lehet a jelentősége a keringő mikro-RNS-eknek a mellékvesekéreg-rák preoperatív diagnosztikájában minimálisan invazív markerként, hiszen jelenleg nincs vérből vizsgálható megbízható preoperatív markere e ritka, de rossz prognózisú daganatnak.

Anyagi támogatás: E munkát a Nemzeti Kutatási Fejlesztési és Innovációs Hivatal (NKFIH) dr. Igaz Péter által elnyert Kl15398. számú pályázata támogatta.

Szerzői munkamegosztás: Az összefoglaló cikk megírásában valamennyi szerző részt vett. A cikk végleges változatát mindegyik szerző elolvasta és jóváhagyta.

Érdekeltségek: A szerzőknek nincsenek érdekeltségeik.

\section{Irodalom}

[1] Libé R. Adrenocortical carcinoma (ACC): diagnosis, prognosis, and treatment. Front Cell Dev Biol. 2015; 3: 45.

[2] Else T, Kim AC, Sabolch A, et al. Adrenocortical carcinoma. Endocr Rev. 2014; 35: 282-326.

[3] Paganini AM, Guerrieri M, Balla A, et al. Management of adrenal incidentaloma by laparoscopic transperitoneal anterior and submesocolic approach. Langenbecks Arch Surg. 2016; 401: 71-79.

[4] Fassnacht M, Kroiss M, Allolio B. Update in adrenocortical carcinoma. J Clin Endocrinol Metab. 2013; 98: 4551-4564.

[5] Assié G, Letouzé E, Fassnacht M, et al. Integrated genomic characterization of adrenocortical carcinoma. Nat Genet. 2014; 46: 607-612.

[6] Malumbres M. miRNAs and cancer: An epigenetics view. Mol Aspects Med. 2013; 34: 863-874.

[7] Muljo SA, Kanellopoulou C, Aravind L. MicroRNA targeting in mammalian genomes: genes and mechanisms. Wiley Interdiscip Rev Syst Biol Med. 2010; 2: 148-161.

[8] Igaz P, Igaz I, Nagy Z, et al. MicroRNAs in adrenal tumors: relevance for pathogenesis, diagnosis, and therapy. Cell Mol Life Sci. 2015; 72: 417-428.

[9] Tömböl Z, Szabó PM, Molnár V, et al. Integrative molecular bioinformatics study of human adrenocortical tumors: microRNA, tissue-specific target prediction, and pathway analysis. Endocr Relat Cancer 2009; 16: 895-906.

[10] Weber JA, Baxter DH, Zhang S, et al. The microRNA spectrum in 12 body fluids. Clin Chem. 2010; 56: 1733-1741.

[11] Chabre O, Libé R, Assie G, et al. Serum miR-483-5p and miR195 are predictive of recurrence risk in adrenocortical cancer patients. Endocr Relat Cancer 2013; 20: 579-594.

[12] Schmitz KJ, Helwig J, Bertram S, et al. Differential expression of microRNA-675, microRNA-139-3p and microRNA-335 in benign and malignant adrenocortical tumours. J Clin Pathol. 2011; 64: 529-535.

[13] Feinmesser M, Benbassat C, Meiri E, et al. Specific microRNAs differentiate adrenocortical adenomas from carcinomas and correlate with Weiss histopathologic system. Appl Immunohistochem Mol Morphol. 2015; 23: 522-531.

[14] Özata DM, Caramuta S, Velázquez-Fernández D, et al. The role of microRNA deregulation in the pathogenesis of adrenocortical carcinoma. Endocr Relat Cancer 2011; 18: 643-655.

[15] Soon PS, Tacon LJ, Gill AJ, et al. miR-195 and miR-483-5p identified as predictors of poor prognosis in adrenocortical cancer. Clin Cancer Res. 2009; 15: 7684-7692.

[16] Patterson EE, Holloway AK, Weng J, et al. MicroRNA profiling of adrenocortical tumors reveals miR-483 as a marker of malignancy. Cancer 2011; 117: 1630-1639.

[17] Koperski Ł, Kotlarek M, Świerniak M, et al. Next-generation sequencing reveals microRNA markers of adrenocortical tumors malignancy. Oncotarget 2017; 8: 49191-49200.

[18] Duregon E, Rapa I, Votta A, et al. MicroRNA expression patterns in adrenocortical carcinoma variants and clinical pathologic correlations. Hum Pathol. 2014; 45: 1555-1562.

[19] Gara SK, Wang Y, Patel D, et al. Integrated genome-wide analysis of genomic changes and gene regulation in human adrenocortical tissue samples. Nucleic Acids Res. 2015; 43: 9327-9339.

[20] Liu M, Roth A, Yu M, et al. The IGF2 intronic miR-483 selectively enhances transcription from IGF2 fetal promoters and enhances tumorigenesis. Genes Dev. 2013; 27: 2543-2548.

[21] Emmerling VV, Fischer S, Kleemann M, et al. miR-483 is a selfregulating microRNA and can activate its own expression via USFl in HeLa cells. Int J Biochem Cell Biol. 2016; 80: 81-86.

[22] Yang ZG, Ma XD, He ZH, et al. miR-483-5p promotes prostate cancer cell proliferation and invasion by targeting RBM5. Int Braz J Urol. 2017; 43: 1060-1067. 
[23] Song Q, Xu Y, Yang C, et al. miR-483-5p promotes invasion and metastasis of lung adenocarcinoma by targeting RhoGDIl and ALCAM. Cancer Res. 2014; 74: 3031-3042.

[24] Cherradi N. microRNAs as potential biomarkers in adrenocortical cancer: Progress and challenges. Front Endocrinol. (Lausanne) 2016; 6: 195 .

[25] Xiao Y, Tian Q, He J, et al. MiR-503 inhibits hepatocellular carcinoma cell growth via inhibition of insulin-like growth factor 1 receptor. Onco Targets Ther. 2016; 9: 3535-3544.

[26] Zhang Y, Chen X, Lian H, et al. MicroRNA-503 acts as a tumor suppressor in glioblastoma for multiple antitumor effects by targeting IGF-1R. Oncol Rep. 2014; 31: 1445-1452.

[27] Long J, Ou C, Xia H, et al. MiR-503 inhibited cell proliferation of human breast cancer cells by suppressing CCNDl expression. Tumour Biol. 2015; 36: 8697-8702.

[28] Dang K, Myers KA. The role of hypoxia-induced miR-210 in cancer progression. Int J Mol Sci. 2015; 16: 6353-6372.

[29] Li L, Huang K, You Y, et al. Hypoxia-induced miR-210 in epithelial ovarian cancer enhances cancer cell viability via promoting proliferation and inhibiting apoptosis. Int J Oncol. 2014; 44: $2111-2120$

[30] Doghman M, El Wakil A, Cardinaud B, et al. Regulation of insulin-like growth factor-mammalian target of rapamycin signaling by microRNA in childhood adrenocortical tumors. Cancer Res. 2010; 70: 4666-4675.

[31] Sun P, Wang L, Lu Y, et al. MicroRNA-195 targets VEGFR2 and has a tumor suppressive role in ACHN cells via PI3K/Akt and Raf/MEK/ERK signaling pathways. Int J Oncol. 2016; 49: $1155-1163$

[32] Luo Q, Zhang Z, Dai Z, et al. Tumor-suppressive microRNA$195-5 \mathrm{p}$ regulates cell growth and inhibits cell cycle by targeting cyclin dependent kinase 8 in colon cancer. Am J Transl Res. 2016; 8: 2088-2096.

[33] Chen S, Wang L, Yao X, et al. miR-195-5p is critical in REG $\gamma$ mediated regulation of wnt $/ \beta$-catenin pathway in renal cell carcinoma. Oncotarget 2017, 8: 63986-64000.

[34] Zhang Y, Zhang Y, Xiao L, et al. Cooperative repression of insulin-like growth factor type 2 receptor translation by microRNA-195 and RNA-binding protein CUGBPl. Mol Cell Biol. 2017; 37: e00225-17.

[35] Galani V, Lampri E, Varouktsi A, et al. Genetic and epigenetic alterations in meningiomas. Clin Neurol Neurosurg. 2017; 158: 119-125.

[36] Wang YX, Zhang XY, Zhang BF, et al. Initial study of microRNA expression profiles of colonic cancer without lymph node metastasis. J Dig Dis. 2010; 11 : 50-54.

[37] Gao L, Yang Y, Xu H, et al. miR-335 functions as a tumor suppressor in pancreatic cancer by targeting OCT4. Tumour Biol. 2014; 35: 8309-8318.
[38] Liu ZF, Liang ZQ, Li L, et al. MiR-335 functions as a tumor suppressor and regulates survivin expression in osteosarcoma. Eur Rev Med Pharmacol Sci. 2016; 20: 1251-1257.

[39] Wang K, Chen X, Zhan Y, et al. miR-335 inhibits the proliferation and invasion of clear cell renal cell carcinoma cells through direct suppression of $B C L-W$. Tumour Biol. 2015; 36: 68756882.

[40] Dong L, Deng J, Sun ZM, et al. Interference with the $\beta$-catenin gene in gastric cancer induces changes to the miRNA expression profile. Tumour Biol. 2015; 36: 6973-6983.

[41] Tissier F, Aubert S, Leteurtre E, et al. Adrenocortical tumors: improving the practice of the Weiss system through virtual microscopy: a National Program of the French Network INCaCOMETE. Am J Surg Pathol. 2012; 36: 1194-1201.

[42] Jung M, Schaefer A, Steiner I, et al. Robust microRNA stability in degraded RNA preparations from human tissue and cell samples. Clin Chem. 2010; 56: 998-1006.

[43] Perge P, Nagy Z, Decmann Á, et al. Potential relevance of microRNAs in inter-species epigenetic communication, and implications for disease pathogenesis. RNA Biol. 2017; 14: 391-401.

[44] Patel D, Boufraqech M, Jain M, et al. MiR-34a and miR-483-5p are candidate serum biomarkers for adrenocortical tumors. Surgery $2013 ; 154:$ 1224-1228.

[45] Salvianti F, Canu L, Poli G, et al. New insights in the clinical and translational relevance of miR483-5p in adrenocortical cancer. Oncotarget 2017; 8: 65525-65533.

[46] Szabó DR, Luconi M, Szabó PM, et al. Analysis of circulating microRNAs in adrenocortical tumors. Lab Invest. 2014; 94: 331-339. [Epub 2013 Dec 16]

[47] Perge P, Butz H, Pezzani R, et al. Evaluation and diagnostic potential of circulating extracellular vesicle-associated microRNAs in adrenocortical tumors. Sci Rep. 2017; 7: 5474.

[48] Zhang J, Li S, Li L, et al. Exosome and exosomal microRNA: trafficking, sorting, and function. Genomics Proteomics Bioinformatics 2015 ; 13 : 17-24.

[49] Nagy Z, Baghy K, Hunyadi-Gulyás E, et al. Evaluation of 9-cis retinoic acid and mitotane as antitumoral agents in an adrenocortical xenograft model. Am J Cancer Res. 2015; 5: 36453658.

[50] Jung S, Nagy Z, Fassnacht M, et al. Preclinical progress and first translational steps for a liposomal chemotherapy protocol against adrenocortical carcinoma. Endocr Relat Cancer 2016; 23: 825837.

(Igaz Péter dr., Budapest, Szentkirályi u. 46., 1088 e-mail: igaz.peter@med.semmelweis-univ.hu)

Az Orvosi Hetilap egyes számai megvásárolhatók a Mediprint Orvosi Könyvesboltban.

Cím: Budapest V., Múzeum krt. 17. - Telefon: 317-4948 